\title{
Somatodendritic Internalization and Perinuclear Targeting of Neurotensin in the Mammalian Brain
}

\author{
Marie-Pierre Faure, ${ }^{1, a}$ Angel Alonso, ${ }^{1}$ Dominique Nouel, ${ }^{1}$ Georges Gaudriault, ${ }^{2}$ Michael Dennis, ${ }^{3}$ Jean-Pierre \\ Vincent, ${ }^{2}$ and Alain Beaudet ${ }^{1}$ \\ 'Montreal Neurological Institute, Montreal, Quebec, H3A 2B4, Canada, 'Institut de Pharmacologie Moléculaire et \\ Cellulaire, Centre National de la Recherche Scientifique, UPR 0411, Université de Nice Sophia-Antipolis, Sophia- \\ Antipolis, 06560 Valbonne, France, and ${ }^{3}$ BioSignal Inc., Montreal, Quebec, H3J 1R4, Canada
}

\begin{abstract}
Polypeptide hormones and growth factors have long been known to internalize into peripheral target cells as a result of their interaction with cell surface receptors. Studies in culture have suggested that certain neuropeptides might undergo a similar type of translocation in neurons. To investigate this possibility in adult mammalian brain, we have examined by confocal laser microscopy the events that follow the binding of fluorescein-tagged derivatives of the tridecapeptide neurotensin to basal forebrain cholinergic cells. Our results demonstrate a selective time- and temperature-dependent internalization of fluo-neurotensin in these cells. This internalization is receptor mediated, proceeds from the entire somatodendritic membrane of the cells, and utilizes endosome-like organelles which are mobilized from dendrites to perikarya and from the periphery of the cell to its perinuclear region. Parallel studies carried out on Sf9 insect cells expressing the rat neurotensin receptor from a recombinant baculovirus indicated that the internalization process involves receptor-ligand complexes and not merely the fluorescent peptide itself. These data suggest that receptor internalization plays a role in neuropeptide signaling in the brain and that it can be harnessed for selective identification of neuropeptide target cells.
\end{abstract}

[Key words: neurotensin, internalization, receptor, confocal laser scanning microscopy, basal forebraln]

A variety of signaling molecules, mainly comprised of peptide hormones and growth factors, have been shown to rapidly enter their target cells after interacting with specific cell surface receptors (Pastan and Willingham, 1981; Posner et al., 1981; Goldstein et al., 1985; Smythe and Warren, 1991). This process, referred to as receptor-mediated internalization, is believed to involve local clustering of the receptors followed by their endocytosis via clathrin-coated pits (Pastan and Willingham, 1981; Goldstein et al., 1985; Keen, 1990; Sorkin and Carpenter, 1993).

\footnotetext{
Received Aug. 10, 1994; revised Dec. 5, 1994; accepted Dec. 7, 1994.

The technical assistance of Beverley Lindsay and Kathy Leonard is grate fully acknowledged. This work was supported by the Medical Research Council of Canada.

Correspondence should be addressed to Dr. Alain Beaudet. Montreal Neurological Institute, 3801 University Street, Montreal, Quebec, H3A 2B4, Canada.

"Piesent address: Advanced Bioconcept Inc., 1801 McGill College Avenue, Room 720, Montreal, Quebec, H3A 2N4, Canada.

Copyright $(1995$ Society for Neuroscience $\quad 0270-6474 / 95 / 154140-08 \$ 05.00 / 0$
}

Although mainly documented for large polypeptides acting through receptor tyrosine kinases (Carpenter and Cohen, 1976; Posner et al., 1981; Knutson, 1991; Wiley et al., 1991; Sorkin and Waters, 1993), receptor-mediated internalization also has been reported for a number of smaller peptides acting through G-protein-coupled receptors. For instance, biochemical and/or histochemical studies have provided evidence for receptor-induced internalization of somatostatin- (Morel et al., 1986) as well as of gonadotropin- (Hazum et al., 1980; Naor et al., 1981; Pelletier et al., 1982; Duello et al., 1983; Wynn et al., 1986; Morel et al., 1987), corticotropin- (Leroux and Pelletier, 1984), and thyrotropin- (Morel et al., 1985) releasing hormones in cells of the anterior pituitary. There have also been reports on the internalization of cholecystokinin (Williams et al., 1982), vasoactive intestinal peptide (VIP; Svoboda et al., 1988; Anteunis et al., 1989), and somatostatin (Viguerie et al., 1987) in pancreatic acinar cells, VIP in intestinal epithelial cells (Izzo et al., 1991), vasopressin in kidney and smooth muscle cells (Lutz et al., 1990), and angiotensin II (Husain et al., 1987) in adrenal glomerulosa cells.

Recent work on the tridecapeptide neurotensin (NT) has suggested that these small peptides may also be internalized into nerve cells. Thus, autoradiographic and/or biochemical studies have shown radioactive NT to be rapidly taken up by mouse and rat neurons in culture in a temperature- and receptor-dependent fashion (Mazella et al., 1991; Vanisberg et al., 1991; Beaudet et al., 1994). This internalization process was shown to initially promote the rapid appearance of a new pool of NT binding sites on the cell membrane (Chabry et al., 1993) and to later result in a downregulation of cell surface receptors (Vanisberg et al., 1991). It has also been implicated in the initiation of the retrograde axonal transport of ${ }^{125} \mathrm{I}-\mathrm{NT}$ observed in nigrostriatal neurons following intrastriatal injections of this radioligand (Castel et al., 1990, 1992; Beaudet et al., 1994). However, there is still no information on the extent and selectivity of NT internalization in mammalian brain, or on the mechanisms that subserve it. It is unclear, in particular, whether this phenomenon: (1) involves the ligand alone or receptor-ligand complexes; (2) proceeds from the entire neuronal surface or is restricted to specialized areas of the cells; and (3) is carried out through classical endocytic pathways. To clarify these issues, we have examined the binding and internalization of novel fluorescein-tagged derivatives of NT in slices of the rodent basal forebrain. This region was selected because it had previously been shown to harbor high concentrations of NT receptors (Moyse et al., 1987) 
which are selectively associated with the perikarya and dendrites of acetylcholinesterase-containing (i.e., of presumptive cholinergic) neurons (Szigethy and Beaudet, 1987; Szigethy et al., 1989). To further document the cellular mechanisms underlying NT internalization and determine whether this process was mediated through the cloned NT receptor (Tanaka et al., 1990), parallel studies were carried out on $\mathrm{Sf} 9$ insect cells expressing the rat NT receptor from a recombinant baculovirus. This model system, which has previously been used to study the biochemical properties of other types of G-protein-coupled receptors (Mouillac et al., 1992), has the advantage of generating considerably higher levels of receptors than mammalian cells while maintaining their normal pharmacological properties (Wong et al., 1990; Mouillac et al., 1992).

\section{Materials and methods}

Fluorescent ligands. Three different fluorescent-tagged NT derivatives were used in the present experiments. The first [ $\mathrm{N} \alpha$-fluoresceinyl thiocarbamyl (FTC)-[Glu! $\left.] \mathrm{NT}^{\prime}\right]$ was selectively labeled on the terminal $\alpha$-amine function of [Glu'] NT using a solid phase methodology and purified by reverse-phase HPLC as described (Faure et al., 1994). The second [N $\alpha$-fluoresceinyl-NT (2-13)] was obtained by incorporating a fluoresceinyl group on the terminal $\alpha$-amine function of NT (2-13). This derivative was prepared by reacting the $\mathrm{N}$-hydroxysuccinimide ester of fluorescein with NT (2-13) at pH 6.5 (Gaudriault and Vincent, 1992), and purified by reverse-phase HPLC. Both of these compounds were found to inhibit specific ${ }^{125}$ I-NT binding to mouse brain membrane preparations with apparent affinities $(\mathrm{Ki})$ virtually identical to those of the native peptide (Faure et al., 1994; G. Gaudriault and J.-P. Vincent, unpublished observations). They also yielded identical confocal microscopic results and were hence used interchangeably. Both are referred to in the text under the generic term fluo-NT.

The third compound (fluo-azido-nitro NT) was a photoreactive derivative of No-fluoresceinyl-NT (2-13). In addition to the fluorophore incorporated on its N-terminal end, this analog was also substituted on the $\epsilon$-amine function of Lys6 by an azido-nitro group. The fluorescent photoreactive analog was synthesized by reacting $\mathrm{N} \alpha$-fluoresceinyl-NT (2-13) with sulfosuccinimidyl 6-(4'-azido-2'-nitrophenylamino) hexanoate (sulfo-SANPAH, Pierce) at pH 8.5 (Gaudriault and Vincent, 1992), and purified by reverse-phase HPLC. The advantage of this compound is that it may be covalently crosslinked to receptor proteins by photoactivation at $320-350 \mathrm{~nm}$, a condition which limits damage to biomolecules and cells by irradiation (Ballmer-Hofer et al., 1982). However, because of the presence of a reactive group on the side chain of Lys6, the affinity of the photoreactive analog for the NT receptor is approximately five times lower than that of NT (Mazella et al., 1985).

Labeling of NT receptors in brain slices. Adult male Sprague-Dawley rats $(n=10)$ were killed by decapitation. The brain was rapidly removed and immersed in a cold oxygenated $\left(95 \% \mathrm{O}_{2}, 5 \% \mathrm{CO}_{2}\right)$ Ringer solution containing $130 \mathrm{~mm} \mathrm{NaCl}, 20 \mathrm{~mm} \mathrm{NaHCO}, 1.25 \mathrm{~mm} \mathrm{KH}_{2} \mathrm{PO}_{4}$, $1.3 \mathrm{mM} \mathrm{MgSO}_{4}, 5 \mathrm{~mm} \mathrm{KCl}, 10 \mathrm{~mm}$ glucose, and $2.4 \mathrm{mM} \mathrm{CaCl}_{2}$. Blocs of basal forebrain were sliced at $350 \mu \mathrm{m}$ thickness on a vibratome. The slices were equilibrated for $45 \mathrm{~min}$ in oxygenated Ringer at room temperature, superfused for $3 \mathrm{~min}$ with $20 \mathrm{nM}$ fluo-NT at $37^{\circ} \mathrm{C}$, and rinsed with oxygenated Ringer for $5,10,15,30,45$, and 60 additional min at $37^{\circ} \mathrm{C}$. To control for nonspecific labeling, additional slices were incubated in the presence of $2 \mu \mathrm{M}$ nonfluorescent NT or with $20 \mathrm{nM}$ fluorescein isothiocyanate (ICN Biomedicals, Cleveland, $\mathrm{OH}$ ) in lieu of fluo-NT. To determine whether the labeling was due to endocytosis, fluo-NT incubations were carried out at $4^{\circ} \mathrm{C}$ or at $37^{\circ} \mathrm{C}$ after preloading the superfusion buffer for $10 \mathrm{~min}$ with $10 \mu \mathrm{M}$ phenylarsine oxide. After rinsing, all slices were fixed for $30 \mathrm{~min}$ at room temperature with $4 \%$ paraformaldehyde in $0.1 \mathrm{M}$ phosphate buffer, placed overnight in $30 \%$ sucrose in the same buffer, snap frozen on the stage of a freezing microtome, and resectioned at $45 \mu \mathrm{M}$ thickness for confocal microscopic examination.

For combined detection of internalized fluo-NT and choline acetyltransferase (ChAT) immunoreactivity, fluo-NT-labeled frozen sections were washed in three consecutive baths of $0.1 \mathrm{M}$ Tris-buffered saline (TBS), incubated $30 \mathrm{~min}$ in $3 \%$ normal rabbit serum in TBS, and then incubated overnight with a 1:400 dilution of ChAT monoclonal antibody (Incstar, Stillwater, MN) in TBS containing 1\% rabbit serum. After several washes $(3 \times 5 \mathrm{~min})$ in TBS, the primary antibody was revealed with a 1:100 dilution of biotinylated goat anti-rat antibody $(60 \mathrm{~min}$ at room temp) followed by streptavidin-Texas red (1:100;30 min at room temp). Sections were then washed $3 \times 5$ min in TBS, mounted with Aquamount, and analyzed by confocal microscopy.

Baculovirus construction and NTR expression in Sf9 cells. A recombinant baculovirus was constructed which encoded the rat NTR cDNA (kindly provided by S. Nakanishi, Kyoto University) using procedures described elsewhere (Mouillac et al., 1992; M. Dennis, unpublished observations). Briefly, the cDNA was subcloned into the baculovirus transfer plasmid pJVETLZ/Nhel and recombinant viruses isolated by plaque purification following cotransfection of plasmid and wild-type AcNPV viral DNA into Sf9 cells. For expression, cultures of Sf9 cells were grown in spinner flasks in Grace's medium containing $10 \%$ fetal bovine serum and infected with the recombinant virus at a multiplicity of infection of 2

Expression of the NTR in Sf9 cells was verified by radioligand binding to membrane preparations. Sf9 cells infected with the NTR virus were harvested at $48 \mathrm{hr}$ postinfection and membranes prepared, as previously described (Mouillac et al., 1992). The membranes (10 $\mu \mathrm{g}$ of protein) were incubated for $20 \mathrm{~min}$ at $25^{\circ} \mathrm{C}$ in $50 \mathrm{~mm}$ Tris- $\mathrm{HCl}$ buffer (pH 7.5) containing various concentrations of $\alpha-^{125} \mathrm{I}$ Bolton Hunter-NT (2-13) (Gaudriault and Vincent, 1992). The incubation was stopped by addition of $2 \mathrm{ml}$ ice-cold buffer and rapid filtration under reduced pressure through cellulose acetate filters (pore size, $0.2 \mathrm{~nm}$; Sartorius). Filters were washed twice with $2 \mathrm{ml}$ of ice-cold buffer. Radioactivity retained on filters was counted with a $\gamma$ counter at a counting efficiency of $80 \%$. Nonspecific binding was measured in the presence of an excess $(1 \mu \mathrm{M})$ of unlabeled NT and subtracted from total binding to oblain specific binding.

Fluo-NT labeling of infected Sf9 cells. Twenty-four to $48 \mathrm{hr}$ after baculovirus infection, St9 cells were rinsed twice in $50 \mathrm{~mm}$ Earle's buffer, pH 7.4, containing $140 \mathrm{~mm} \mathrm{NaCl}, 5 \mathrm{~mm} \mathrm{KCl}, 1.8 \mathrm{~mm} \mathrm{CaCl}_{2}$, $3.6 \mathrm{~mm} \mathrm{MgCl}, 0.1 \%$ bovine serum albumin, and $0.01 \%$ glucose, equilibrated for $10 \mathrm{~min}$ in the same buffer, and labeled with either fluo-NT or fluo-azido-nitro NT.

For fluo-NT labeling, cells $\left(5 \times 10^{4} / \mathrm{ml} ; 0.5 \mathrm{ml} /\right.$ assay) were incubated with $10 \mathrm{~nm}$ fluo-NT in the same buffer for $60 \mathrm{~min}$ at either $-5^{\circ} \mathrm{C}$ or $21^{\circ} \mathrm{C}$ and in the presence or absence of $10 \mu \mathrm{M}$ of the endocytosis inhibitor phenylarsinc oxide. At the end of the incubation, the cells were washed $4 \times 1 \mathrm{~min}$ in cold binding buffer, deposited on glass slides, dried under a cool stream of air, and examined in the confocal microscope under oil immersion. To control for nonspecific binding, the experiments were carried out in the presence of $1 \mu \mathrm{M}$ nonfluorescent NT or on $\mathrm{Sf} 9$ cells infected with a baculovirus encoding the human $\beta$-adrenergic receptor (Mouillac et al., 1992).

For fluo-azido-nitro NT labeling. Sf9 cells were incubated in the dark for $30 \mathrm{~min}$ at $-5^{\circ} \mathrm{C}$ with $20 \mathrm{~nm}$ of fluo-azido-nitro NT in the same buffer as above with and without a hundredfold excess of native NT for determination of nonspecific binding. At the end of the incubation, the cells were subjected or not to three consecutive photographic flashes (Minolta Auto 32; setting, auto; distance from specimen, $25 \mathrm{~cm}$ ), washed $4 \times 1 \mathrm{~min}$ in cold binding buffer, and either fixed in $4 \%$ paraformaldehyde in $0.1 \mathrm{M} \mathrm{PO}_{4}$ buffer for 20 min and dehydrated in graded ethanols for confocal microscopic viewing or warmed up to $21^{\circ} \mathrm{C}$ for a further $45 \mathrm{~min}$ prior to being fixed and dehydrated as above.

Confocal microscopy. Basal forebrain sections and labeled Sf9 cells were both examined under a Leica confocal laser scanning microscope (CLSM) configured with a Leica Diaplan inverted microscope equipped with an argon ion laser $(488 \mathrm{~nm})$ with an output power of $2-50 \mathrm{mV}$ and a VME bus MC 68020/68881 computer system coupled to an optical disc for image storage (Leica, St. Laurent, Canada). All imagegenerating and -processing operations were performed with the LEICA CLSM software package. Micrographs were taken from the image monitor using a Focus Imagecorder (Foster City, California).

Images of the basal forebrain were acquired according to two different modes: (1) serial optical sections $(n=12)$ separated by $0.24 \mu \mathrm{m}$ steps, averaged over four scans/frame and reconstructed (extended focus) over a depth of $3 \mu \mathrm{m}$; and (2) single optical sections averaged over $128 \mathrm{scans} / \mathrm{frame}$. Images of Sf9 cells were acquired as serial optical sections separated by $1.5 \mu \mathrm{m}$ steps and averaged over 32 scans/frame. For all types of acquisitions, the gain and black levels were set manually to optimize the dynamic range of the image while ensuring that no region was completely suppressed (intensity $=0$ ) or completely saturated (intensity $=255$ ). 
Double fluorescence images were acquired in two passes, fluorescein first, Texas red second, to avoid bleeding from one channel into the other. Fluorescent polystyrene beads (diameter $10 \mu \mathrm{m}$; Becton Dickinson) were used to verify that the two emission filters were properly aligned.

Fluorescence intensity measurements were performed on reconstruct cd scrial images of the basal forcbrain (acquisition modc 1) and cxpressed as gray levels per unit area on a 0-255 scale. Values were averaged for 12-14 readings from at least 14 different sections. Morphometric measurements of the diameter, number, and distance from the nuclear center of intracytoplasmic fluorescent particles were performed on individually scanned $10 \mu \mathrm{m}$ thick sections (acquisition mode 2). Results correspond to the mean \pm SEM of four sections. Statistical analyses were performed using one-way analysis of variance (one-way ANOVA), followed by a regression curve analysis. The comparison of the slope from the regression curve was done using a Student's $t$ test.

\section{Results}

\section{Studies on brain slices}

Five minutes after a $5 \mathrm{~min}$ superfusion of rat basal forebrain slices with $20 \mathrm{nM}$ fluo-NT at $37^{\circ} \mathrm{C}$, intense and pervasive fluorescent labeling was detected by confocal microscopy in a selective subset of neurons distributed throughout the medial septal nucleus, the diagonal band of Broca, and the substantia innominata. Although most prominent over neuronal perikarya, the labeling was also apparent over multiple cross-sectioned neuronal processes throughout the neuropil (Fig. 1a). Quantification of the fluorescent signal revealed a 1.5 -fold difference in intensity between perikaryal and neuropil labeling at this time (Table 1). By contrast, sections incubated with a thousandfold excess of native NT, or with fluorescein isothiocyanate in lieu of fluoNT, showed no significant fluorescent signal over background noise, indicating that fluo-NT labeling was dependent upon specific binding of fluo-NT to NT receptors. Slices exposed to fluo$\mathrm{NT}$ at $4^{\circ} \mathrm{C}$, or at $37^{\circ} \mathrm{C}$ in the presence of the endocytosis inhibitor phenylarsine oxide, were also devoid of significant fluorescent signal, indicating that the observed labeling resulted from a temperature-dependent endocytic process. In conformity with these data, serial optical sectioning of fluo-NT-labeled cell bodies revealed that most, if not all, of the observed fluorescent signal was intracellular. Slow scanning of single optical sections passing through the core of the cells further indicated that the internalized fluorescence was confined to small, spherical particles distributed throughout the cytoplasm (Fig. 1c).

Between 5 and $30 \mathrm{~min}$ after application of the fluorescent ligand, the labeling became progressively more intense over neuronal perikarya and proportionally less intense over neuronal processes ('Table 1). By $60 \mathrm{~min}$, the fluorescent signal had increased by $19 \%$ over nerve cell bodies and had dropped to background levels in the surrounding neuropil (Fig. 1b; Table 1). Throughout this time period, the label remained in the form of small, intensely fluorescent particles (Fig. 1d). However, the mean diameter of these particles increased linearly with time $[\mathrm{F}(1,20)=11.4, p<0.01 ; \mathrm{Fig} .2 A]$. In addition, the number of particles per unit of labeled cell cross-sectional area decreased linearly with time $[\mathrm{F}(1,19)=13.38, p<0.01$; Fig. $2 B]$. These two events were significantly inversely correlated $(r--0.98$; $p<0.001$ ). Finally, when the mean distance between each perikaryal fluorescent particle and the center of the nucleus was plotted as a function of time, a statistically significant overall translation of the particles from the periphery to the center of the cell was apparent $[\mathrm{F}(1,11)=4.86, p<0.05$; Fig. $2 C]$. This movement was such that by $60 \mathrm{~min}$, the bulk of fluorescent particles was confined to the perinuclear zone (Fig. 1d).

To demonstrate that the observed cellular labeling was selec- tive for cholinergic neurons-that is, for neurons known to be selectively endowed with NT receptors in this region of the brain-slices exposed to fluo-NT at $37^{\circ} \mathrm{C}$ were washed for 45 min and double labeled by immunofluorescence using a specific antibody against the acetylcholine biosynthetic enzyme choline acetyltransferase (ChAT). Confocal microscopic examination of this dually stained material revealed that the large majority of the cells that had internalized fluo NT $(88.9 \pm 2.0 \%)$ also stained positively for ChAT (Fig. le,f).

\section{Studies on Sf 9 cells}

To further characterize the mechanisms underlying the internalization of fluo-NT molecules, experiments were conducted with Sf9 insect cells infected $24-48 \mathrm{hr}$ earlier with a baculovirus encoding the cloned NT receptor. Membranes prepared from infected cells at $48 \mathrm{hr}$ postinfection bound ${ }^{125} \mathrm{I}-\mathrm{NT}$ with a maximal binding capacity $\left(B_{\text {max }}\right)$ of $12.4 \mathrm{pmol} / \mathrm{mg}$ protein and an apparent dissociation constant $(\mathrm{Kd})$ of $0.38 \mathrm{~nm}$. Scatchard analysis of the data (not shown) indicated the presence of a single class of NT binding sites.

Incubation of infected Sf 9 cells with $10 \mathrm{~nm}$ fluo-NT at room temperature resulted in a time-dependent internalization of the fluorescent probe (Fig. $3 a-c$ ). Serial optical sectioning of the cells in the confocal microscope revealed that as in neurons, internalized ligand molecules were confined to small endosomelike particles (Fig. 3b,c, arrows). By contrast, in cells incubated at low temperature or in the presence of the endocytosis inhibitor phenylarsine oxide, specifically bound fluo-NT molecules remained clustered on the surface of the cells (Fig. 3d-f). Neither binding nor internalization of fluo-NT were observed in the presence of an excess of nonfluorescent NT or in control Sf9 cclls infected with a baculovirus encoding the human $\beta$-adrenergic in lieu of the rat NT receptor.

To determine whether the internalization process involved the ligand alone or ligand-receptor complexes, Sf9 cells were incubated with fluo-azido-nitro NT, a photoaffinity derivative of fluo-NT, in lieu of fluo-NT. In a first step, the cells were incubated for $30 \mathrm{~min}$ at $-5^{\circ} \mathrm{C}$ to label surface receptors. They were then subjected to a photographic flash and washed thoroughly to dissociate non-cross-linked ligand molecules from their receptors. As can be seen in Figure 4, the labeling achieved under these conditions was confined to the cell surface (Fig. 4a) and was not detectable in cells that had not been exposed to a flash of light (Fig. 4b). Both irradiated and control (nonirradiated) cells were then warmed to room temperature for a further 45 min, at which time the pattern of labeling in irradiated cells was indistinguishable from that observed with fluo-NT (Fig. 4c). Here again, cells that had not been subjected to photoirradiation remained label free (Fig. $4 d$ ).

\section{Discussion}

The present results provide the first demonstration of receptorinduced internalization of a neuropeptide in live brain slices. Evidence that this internalization represents a true receptor-mediated event and not merely a nonspecific endocytic process includes: (1) the fact that the labeling was no longer apparent when the incubation was carried out in the presence of an excess of nonfluorescent NT; (2) the absence of internalization of free fluorescein; and (3) the selectivity of the internalization process for cholinergic cells which earlier autoradiographic studies had shown to be selectively endowed with high-affinity NT binding sites in the basal forebrain (Szigethy and Beaudet, 1987; Szig- 

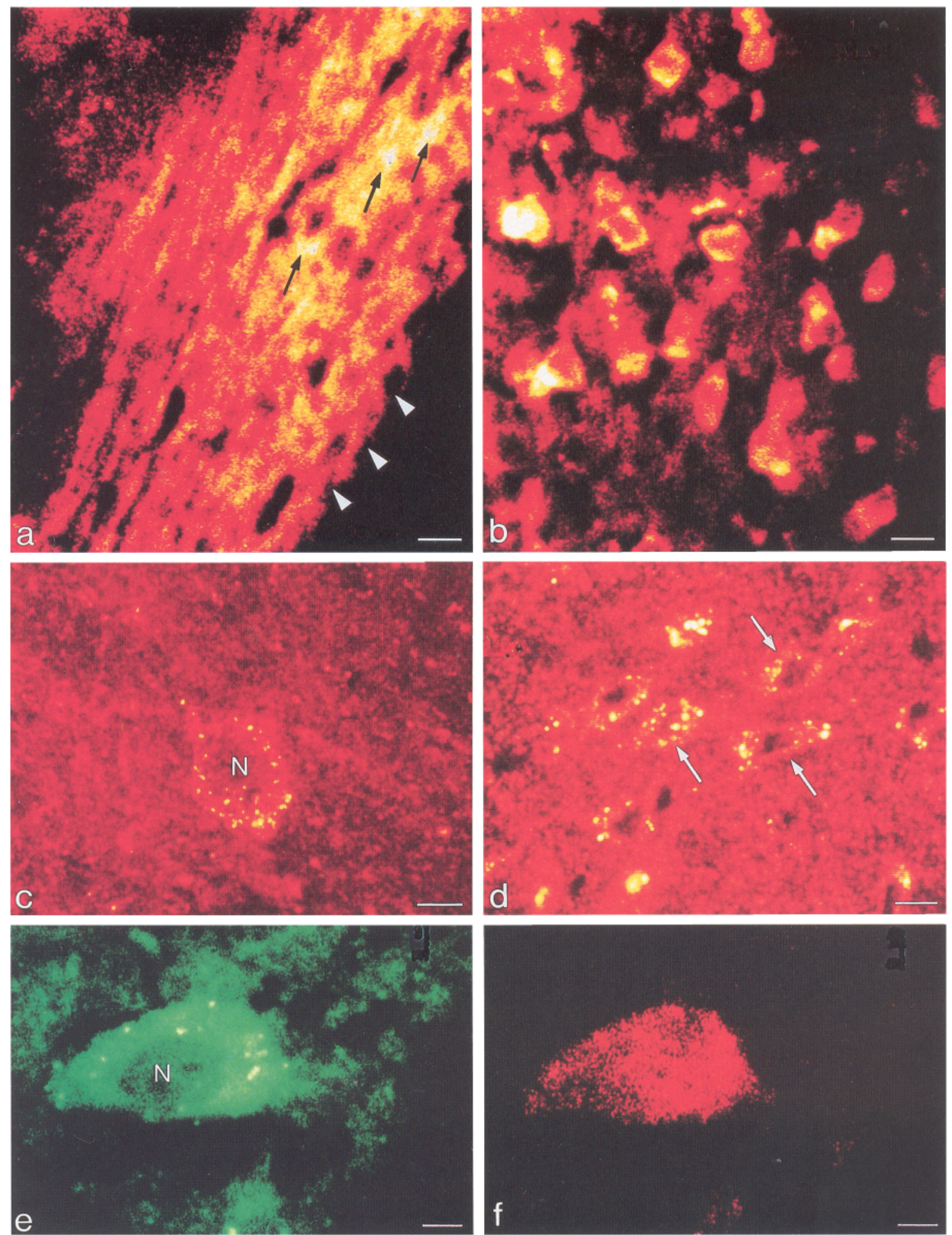

Figure 1. $a-d$, Confocal microscopic imaging of fluo-NT labeling in rat basal forebrain slices. Sections scanned after $5(a, c)$ and $60(b, d)$ min of fluo-NT washout. Images in $a$ and $b$ are reconstructed from a stack of 12 serial optical sections scanned at low resolution (four scans/frame). At $5 \mathrm{~min}(a)$, labeling in the diagonal band of Broca is evident over both perikarya (arrows) and neuropil. Arrowheads mark the base of the brain. At $60 \mathrm{~min}(b)$, nerve cell bodies in the same region stand out against a markedly reduced neuropil labeling. Images in $c$ and $d$ are single optical sections scanned at high resolution (128 scans/frame). At $5 \mathrm{~min}(c)$, fluo-NT is seen to be contained in small, endosome-like particles distributed throughout the cytoplasm of a single NT-receptive cell. At $60 \mathrm{~min}(d)$, labeled cells (arrows) exhibit a lesser number of larger fluorescent particles. $e, f$, Basal forebrain neuron dually labeled for fluo-NT $(e)$ and ChAT $(f)$. Images were acquired as in $a$ and $b$, but using two different channels to avoid an overlap of fluorophore emission spectra. Note the presence in $e$ of endosome-like particles that are not visible in the ChAT-immunoreactive cell. $N$, nucleus. Scale bars in $a-d, 10 \mu \mathrm{m} ; e, f, 5 \mu \mathrm{m}$. 
Table 1. Densitometric analysis of fluorescence intensity in slices of rat basal forebrain incubated with fluo-NT

\begin{tabular}{lrll}
\multirow{2}{*}{$\begin{array}{l}\text { Washout } \\
\text { time }\end{array}$} & \multicolumn{3}{l}{ Fluorescence intensity* } \\
\cline { 2 - 4 } & \multicolumn{1}{l}{ Perikarya } & Neuropil & Perikarya/neuropil \\
\hline $5 \mathrm{~min}$ & $85.73 \pm 5.40$ & $64.74 \pm 3.79$ & $1.52 \pm 0.11$ \\
$30 \mathrm{~min}$ & $92.00 \pm 7.37$ & $55.19 \pm 8.96$ & $1.97 \pm 0.23$ \\
$60 \mathrm{~min}$ & $101.94 \pm 3.43$ & $43.28 \pm 5.17$ & $2.51 \pm 0.28$
\end{tabular}

* Gray levels/unit area on a 0-255 scale. Values represent the mean \pm SEM of 12-14 readings from at least four different slices. Perikaryal values inversely correlated with neuropil ones $(r=-0.99)$ with $p<$ 0.001 .

ethy et al., 1989). That the internalization process was indeed selective for cholinergic cells was demonstrated here by the results of our double-labeling experiments, which showed close to $90 \%$ of fluo-NT-labeled cells to stain positively for choline acetyltransferase. In keeping with these observations, electrophysiological studies from our laboratory (Alonso et al., 1994) have demonstrated that bath application of fluo-N'l onto slices of the guinea pig basal forebrain induced membrane depolarization and the cmergence of a slow complex rhythmic bursting pattern in neurons exhibiting electrophysiological properties characteristic of cholinergic cells (Khateb et al., 1992). Fluo-NT clearly acted as an agonist since native NT induced equivalent responses when applied to the same neurons (Alonso et al., 1994). The internalization process documented in the present study is therefore likely to be triggered by receptor activation, although the sequence of events that link these two phenomena remains to be established.

Neurons expressing the NT receptor cloned by Tanaka et al. (1990) have been visualized in the basal forebrain of the rat using in situ hybridization histochemistry (Elde et al., 1990; Sato et al., 1992; Nicot et al., 1994), suggesting that this isoform might be responsible for the internalization of fluo-NT observed in the present study. Our binding experiments on membranes of Sf9 cells infected with a baculovirus encoding this molecular form of the receptor indicated that ${ }^{125} \mathrm{I}-\mathrm{NT}$ bound to the transfected receptor with a $\mathrm{Kd}$ value in good agreement with that reported for the NT receptor in rat brain. Confocal microscopic studies of these cells using fluo-NT indicated that these cell surface receptors could indeed mediate internalization of the peptide, in conformity with recent biochemical data from mammalian cell lines transfected with the same clone (Chabry et al., 1994; Hermans et al., 1994b).

The fact that the internalization of fluo-NT could be blocked in both basal forebrain cholinergic and Sf9-infected cells hy either lowering the temperature or preincubating the cells with the endocytosis inhibitor phenylarsine oxide indicated that the internalization process was endocytic in nature. Indeed, the pattern of punctate intracellular fluorescence observed in our material was reminiscent of that described following receptor-mediated endocytosis of fluorescent peptide ligands in other cell types (Hazum et al., 1980; Naor et al., 1981; Lutz et al., 1990). Experiments in Sf9 cells showed this pattern to remain essentially unchanged when the ligand was covalently crosslinked to the receptor prior to internalization, demonstrating that this endocytic process involved receptor-ligand complexes and not merely the fluorescent probe.

In brain slices, internalization of fluo-NT molecules was
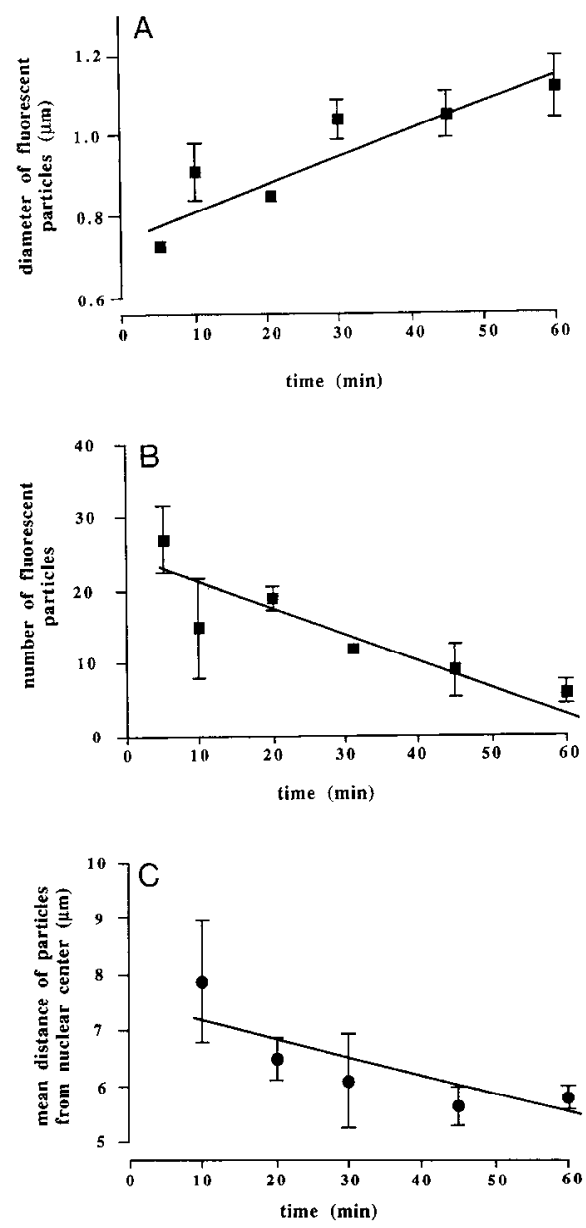

Figure 2. Evolution over time of the mean diameter (in micrometers, $A)$, number $(B)$, and distance to the nuclear center (in micrometers, $C$ ) of fluorescent endosome-like particles in fluo-NT-labeled basal forebrain neurons. Slices from the rat basal forebrain were labeled as described in Figure 1 and scanned under the confocal microscope 5-60 min after a single 3 min pulse of $20 \mathrm{~nm}$ fluo-NT. All measurements were made on single optical sections scanned at high resolution (128 scans/frame, Fig. $1 c, d)$. Mean \pm SEM of 12 slices from three animals. Statistical analysis was performed using a one-way analysis of variance (ANOVA) followed by a regression analysis.

found to proceed from the entire somatodendritic arbor of basal forebrain cholinergic cells, in conformity with our earlier electron microscopic demonstration of a diffuse distribution of N'I receptors on the membrane of these cells (Szigethy et al., 1990). The internalization process was rapidly followed by a concomitant decrease in neuropil labeling and increase in perikaryal fluorescence which can best be explained by a migration of internalized receptor-ligand complexes from dendrites to nerve cell bodies. Studies on embryonic neurons in culture have previously documented the existence of a similar dendritic transport for constitutively internalized molecules (e.g., transferrin, horseradish peroxidase; Parton et al., 1992), but the present results provide, to our knowledge, the first experimental evidence for a dendritic transport of internalized neuropeptide molecules within nerve cells.

The time-dependent reduction in number and inversely correlated increase in size of intracellular fluorescent granules observed in the course of their migration from the periphery to the perinuclear region of the cells is congruent with the evolution of endosomes into multivesicular bodies and ultimately into ly- 

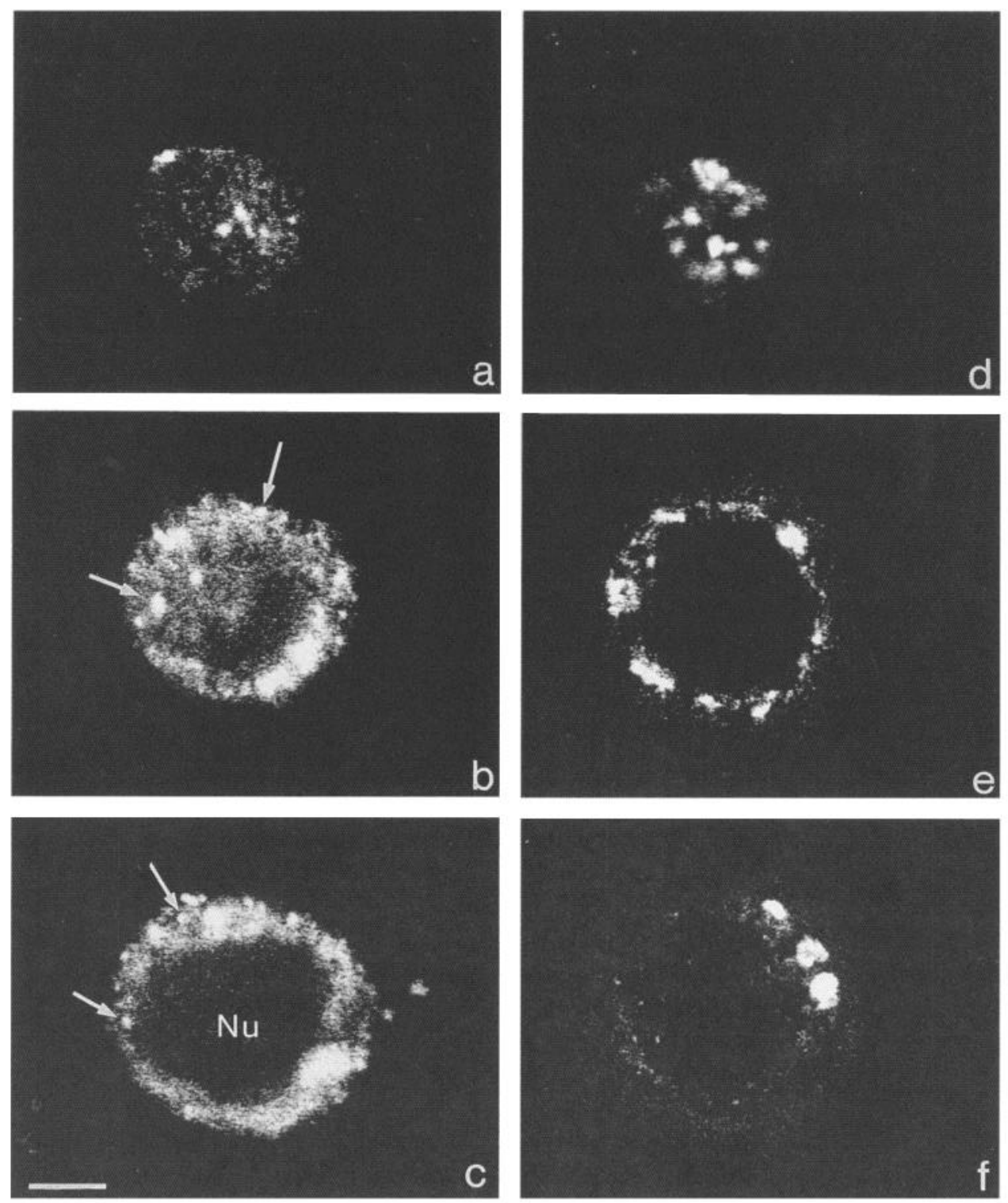

Figure 3. Confocal microscopic imaging of Sf9 insect cells infected with a baculovirus encoding the cloned NT receptor and labeled with $10 \mathrm{~nm}$ fluoNT for $60 \mathrm{~min}$ at either $21^{\circ} \mathrm{C}(a-c)$ or $-5^{\circ} \mathrm{C}(d-f)$. Serial optical sections taken at $1.5 \mu \mathrm{m}$ intervals from the surface of the cells $(a, d)$ inward $(b, c ; e$, $f$ ). In sections grazing the cell surface $(a, d)$, the ligand forms small, irregular clusters that are most evident in cells incubated at $-5^{\circ} \mathrm{C}(d)$. In sections passing through the core of the cells $(b$, $c ; e, f)$, the ligand pervades the cytoplasm in cells incubated at room temperature $(a-c)$, but is confined to the surface in cells incubated at $-5^{\circ} \mathrm{C}(e$, $f)$. Note that the internalized ligand is concentrated within small endosomelike particles (arrows) and does not permeate the nucleus $(\mathrm{Nu})$. Scale bar $10 \mu \mathrm{m}$. sosomes reported in other cell types (Helenius et al., 1983; Hopkins et al., 1990; Van Deurs et al., 1993). This process usually results in a dissociation of receptor-ligand complexes through rapid acidification of the endosomal compartment and, ultimately, differential routing of peptide and receptor, the former to the lysosomal compartment for degradation and the latter to the plasma membrane for recycling (Helenius et al., 1983; Schmid et al., 1988). Had these mechanisms been in place here, however, acidification of the endosomal compartment should have quenched the fluorescence of our FITC-tagged ligand (Lutz et al., 1990), which it did not. Furthermore, recent biochemical studies on cerebral neurons in culture have demonstrated that the density of cell surface NT receptors was unaffected by the carboxylic ionophore monensin, a compound known to disrupt intracellular traffic and the recycling of many receptors, from which it was concluded that NT receptors were not recycled (Chabry et al., 1993). Finally, studies of in vivo retrograde transport of ${ }^{125} \mathrm{I}-\mathrm{NT}$ in nigrostriatal neurons have shown intracellular ${ }^{125} \mathrm{I}-\mathrm{NT}$ molecules to be remarkably resistant to metabolic degradation for up to $4 \mathrm{hr}$ after ${ }^{125} \mathrm{I}-\mathrm{NT}$ injection (Castel et al.,
1991), a finding difficult to reconcile with the exclusive routing of internalized NT toward lysosomes. Thus, although additional studies using specific organelle markers are clearly required for further identification of fluo-NT's sequestration compartments, available data suggest that these may differ significantly from those of classical endocytic pathways.

The physiological significance of the internalization and somatopetal transport of NT demonstrated here in basal forebrain cholinergic cells is still largely conjectural. One obvious function is the clearance of bound ligand molecules. This interpretation is supported by the recent demonstration of immunoreactive endopeptidase 24.16 , a metallopeptidase involved in the functional inactivation of NT, within putative NT target cells in the rat CNS (Woulfe et al., 1992). Internalization of receptorligand complexes has also been linked to "cellular" (as opposed to molecular) desensitization (Laduron, 1994). Indeed, internalization of NT in rat embryonic neurons in culture has been shown to result in a rapid disappearance of NT receptors from the cell surface (Vanisberg et al., 1991). However, internalization should not be viewed as the only mechanism through which NT 

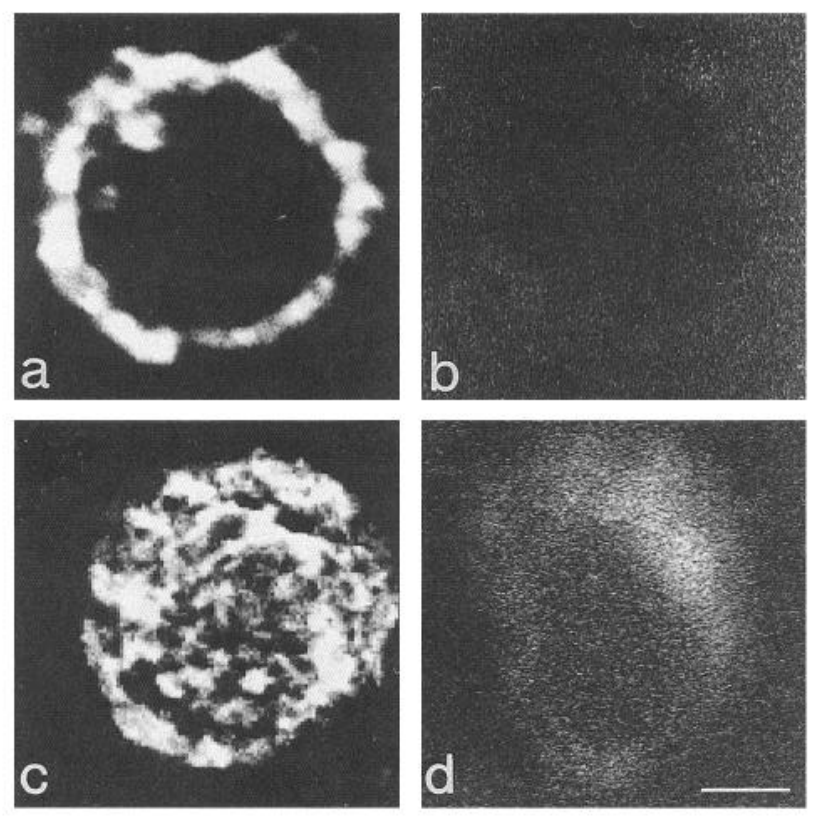

Figure 4. Confocal microscopic imaging of the binding $(a, b)$ and internalization $(c, d)$ of fluo-azido-nitro NT to Sf9 cells infected with a baculovirus coding for the rat NT receptor. Images acquired as in Figure 3. At $-5^{\circ} \mathrm{C}(a, b)$ the label is confined to the cell surface in irradiated cells $(a)$ and virtually undetectable in nonirradiated ones $(b)$. At $21^{\circ} \mathrm{C}(c, d)$, cross-linked fluo-azido-nitro NT molecules have internalized and are detected throughout the cytoplasm in the form of intensely fluorescent particles $(c)$. Here again, nonirradiated controls are negative $(d)$. Scale bar, $5 \mu \mathrm{m}$.

receptor desensitization may occur, since while rapid desensitization of agonist-induced calcium mobilization was observed in PC12 cells, but not in CHO cells transfected with the rat NT receptor, while both cell types internalized ${ }^{125} \mathrm{I}-\mathrm{NT}$ equally well (Hermans, 1994a,b).

Although the present results are clearly suggestive of an intracellular routing of internalized receptor-ligand complexes through intracellular degradation pathways, and thereby of a role of internalization in NT receptor downregulation, the possibility that the internalization process is also involved in long-distance signaling to elicit long-term effects of the ligand in target cells, such as proposed for cytokines, growth factors, and neuropeptides (see Laduron, 1992, for a review), cannot be excluded. In fact, such a mechanism has been invoked to account for the increase in the expression of tyrosine hydroxylase observed in nigrostriatal dopaminergic neurons following intrastriatal injection of NT (Burgevin et al., 1992). The aggregation of internalized ligand molecules in the perinuclear zone observed here in the long term, together with the preservation of NT in unmetabolized form within intracellular sequestration compartments following its intracerebral injection (Castel et al., 1991), is consistent with the hypothesis of an intracellular action of the internalized ligand, receptor, or fragment thereof (see Laduron, 1994).

A variety of neuropeptides have been shown to internalize in peripheral target cells and are therefore likely to internalize within CNS neurons in light of the present results. The possibility that the process described here for NT may thus represent a common consequence of neuropeptide binding to central receptors should therefore be taken into consideration for the interpretation of in vivo pharmacological, including positron emis- sion tomographic, data. In fact, the internalization process may even be used as a tool to selectively identify, as demonstrated in the present study, neuropeptide target neurons in live brain.

\section{References}

Alonso A, Faure MP, Beaudet A (1994) Neurotensin promotes oscillatory bursting behavior and is internalized in basal forebrain cholinergic neurons. J Neurosci 14:5778-5792.

Anteunis A, Astesano A, Portha B, Hejblum G, Rosselin G (1989) Ultrastructural analysis of VIP internalization in rat B- and acinar cells in situ.. Am J Physiol 246:G710-G717.

Ballmer-Hofer K, Schlup V, Burn P, Burger MM (1982) Isolation of in situ cross-linked ligand-receptor complexes using an anticross-linker specific antibody. Anal Biochem 126:246-250.

Beaudet A, Mazella J, Nouel D, Chabry J, Castel MN, Laduron P, Kitabgi P, Faure MP (1994) Internalization and intracellular mobilization of neurotensin in neuronal cells. Biochem Pharmacol 47:43-52.

Burgevin MC, Castel MN, Quarteronet D, Chevet T, Laduron PM (1992) Neurotensin increases tyrosine-hydroxylase messenger RNApositive neurons in substantia nigra after retrograde axonal transport. Neuroscience 49:627-633.

Carpenter G, Cohen S (1976) ${ }^{125}$ I-labelled human epidermal growth factor. Binding, internalization, and degradation in human fibroblasts. J Cell Biol 71:159-171.

Castel MN, Malgouris C, Blanchard JC, Laduron PM (1990) Retrograde axonal transport of neurotensin in the dopaminergic nigrostriatal pathway in the rat. Neuroscience $36: 425-430$.

Castel MN, Faucher D, Cuiné F, Dubédat P, Boireau A, Laduron PM (1991) Identification of intact neurotensin in the substantia nigra after its retrograde axonal transport in dopaminergic neurons. J Neurochem $56: 1816-1818$.

Castel MN, Woulfe J, Wang X, Laduron PM, Beaudet A (1992) Light and electron microscopic localization of retrogradely transported neurotensin in rat nigrostrial dopaminergic neurons. Neuroscience 50: 269-282.

Chabry J, Gaudriault G, Vincent JP, Mazella J (1993) Implication of various forms of neurotensin receptors in the mechanism of internalization of neurotensin in cerebral neurons. J Biol Chem 268:1713817144.

Chabry J, Labbé-Jullié C, Gully D, Kitabgi P, Vincent JP, Mazella J (1994) Stable expression of the cloned rat brain neurotensin receptor into fibroblasts: binding properties, photoaffinity labeling, transduction mechanisms, and internalization. J Neurochem 63:19-27.

Duello TM, Nett TM, Farquhar MG (1983) Fate of a gonadotropin releasing hormone agonist internalized by rat pituitary gonadotrophs. Endocrinology 112:1-10.

Elde R, Schalling M, Ceccatelli S, Nakanishi S, Hökfelt T (1990) Localization of neuropeptide receptor mRNA in rat brain: initial observations using probes for neurotensin and substance $\mathrm{P}$ receptors. Neurosci Lett 120:134-138.

Faure MP, Gaudreau P, Shaw I, Cashman NR, Beaudet A (1994) Synthesis of a biologically active probe for labelling neurotensin receptors. J Histochem Cytochem 42:755-763.

Gaudriault G, Vincent JP (1992) Selective labelling of $\alpha$ - or $\epsilon$-amino groups in peptides by the Bolton-Hunter reagent. Peptides 30:11871192.

Goldstein JL, Brown MS, Anderson RG, Russell DW, Schneider WJ (1985) Receptor-mediated endocytosis: concepts emerging from the LDL receptor system. Annu Rev Cêll Biol 1:1-39.

Hazum E, Cuatrecasas P, Marian J, Conn PM (1980) Receptor-mediated internalization of fluorescent gonadotropin-releasing hormone by pituitary gonadotropes. Proc Natl Acad Sci USA 77:6692-6695.

Helenius A, Mellman JI, Wall D, Hubbard A (1983) Endosomes. Trends Biochem Sci 7:245-250.

Hermans E, Gailly P, Octave JN, Maloteaux JM (1994a) Rapid desensitization of agonist-induced calcium mobilization in transfected $\mathrm{PC} 12$ cells expressing the rat neurotensin receptor. Biochem Biophys Res Commun 198:400-407.

Hermans E, Octave JN, Maloteaux JM (1994b) Receptor mediated internalization of neurotensin in transfected Chinese hamster ovary cells. Biochem Pharmacol 47:89-91.

Hopkins CR, Gibson A, Shipman M, Miller K (1990) Movement of internalized ligand-receptor complexes along a continuous endosomal reticulum. Nature 346:335-339. 
Husain A, DeSilva P, Speth RC, Bumpus FM (1987) Regulation of angiotensin II in rat adrenal gland. Circ Res 60:640-648.

Izzo RS, Scipione RA, Pellecchia C, Lokchander RS (1991) Binding and internalization of VIP in rat intestinal epithelial cells. Regul Pept $33: 21-30$.

Keen JH (1990) Clathrin and associated assembly and disassembly proteins. Annu Rev Biochem 59:415-438.

Khateb A, Muhlethaler M, Alonso A, Serafin M, Mainville L, Jones BE (1992) Cholinergic nucleus basalis neurons display the capacity for rhythmic bursting activity mediated by low threshold calcium spikes. Eur J Neurosci 51:489-494.

Knutson VP (1991) Cellular trafficking and processing of the insulin receptor. FASEB J 5:2130-2138.

Laduron PM (1992) Genomic pharmacology: more intracellular sites for drug action. Biochem Pharmacol 44:1233-1242.

Laduron PM (1994) From receptor internalization to nuclear translocation. New targets for long-term pharmacology. Biochem Pharmacol 47:3-13.

Leroux P, Pelletier G (1984) Radioautographic study of binding and internalization of corticotropin-releasing factor by rat anterior pituitary corticotrophs. Endocrinology 114:14-21.

Lutz W, Sanders M, Salisbury J, Kumar R (1990) Internalization of vasopressin analogs in kidney and smooth muscle cells: evidence for receptor-mediated endocytosis in cells with V2 or V1 receptors. Proc Natl Acad Sci USA 87:6507-6511.

Mazella J, Kitabgi P, Vincent JP (1985) Molecular properties of neurotensin receptors in rat brain. $\mathrm{J}$ Biol Chem 260:508-514.

Mazella J, Leonard K, Chabry J, Kitabgi P, Vincent JP, Beaudet A (1991) Binding and internalization of iodinated neurotensin in neuronal cultures from embryonic mouse brain. Brain Res 564:249-255.

Morel G, Gourdji D, Grouselle D, Brunet N, Tixier-Vidal A, Dubois PM (1985) Immunocytochemical evidence for in vivo internalization of thyroliberin into rat pituitary target cells. Neuroendocrinology 41 : 312-320.

Morel G, Pelletier G, Heisler S (1986) Internalization and subcellular distribution of radiolabeled somatostatin- 28 in mouse anterior pituitary tumour cells. Endocrinology 119:1972-1979.

Morel G, Dihl F, Aubert ML, Dubois PM (1987) Binding and internalization of native gonadoliberin $(\mathrm{GnRH})$ by anterior pituitary gonatrophs of the rat. A quantitative autoradiographic study after cryoultramicrotomy. Cell Tissue Res 248:541-550.

Mouillac B, Caron M, Bonin H, Dennis M, Bouvier M (1992) Agonistmodulated palmitoylation of $\beta_{2}$-adrenergic receptor in Sf9 cells. J Biol Chem 267:21733-21737.

Moyse E, Rostène W, Vial M, Leonard K, Mazella J, Kitabgi P, Vincent JP, Beaudet A (1987) Distribution of neurotensin binding sites in rat brain: a light microscopic radioautographic study using monoiodo [125I]Tyr ${ }^{3}$-neurotensin. Neuroscience 22:525-536.

Naor Z, Atlas D, Clayton RN, Forman DS, Amsterdam A, Catt KJ (1981) Interaction of fluorescent gonadotropin-releasing hormone with receptors in cultured pituitary cells. J Biol Chem 256:30493052 .

Nicot A, Rostène W, Bérod A (1994) Neurotensin receptor expression in the rat forebrain and midbrain: a combined analysis by in situ hybridization and receptor autoradiography. J Comp Neurol 341:407419.

Parton RG, Simons K, Dotti CG (1992) Axonal and dendritic endocytotic pathways in cultured neurons. J Cell Biol 119:123-137.

Pastan IH, Willingham MC (1981) Journey to the cell center: role of the receptosome. Science 214:504-509.
Pelletier I, Dubé F, Gui C, Seguin F, I efehvre A (1982) Binding and internalization of a luteinizing hormone-releasing hormone agonist by rat gonadotrophic cells. A radioautographic study. Endocrinology 111:1068 1076.

Posner BI, Bergeron JJM, Josefsberg Z, Khan MN, Khan RJ, Patel BA, Sikstrom RA, Verma AK (1981) Polypeptide hormones: intracellular receptors and internalization. Recent Prog Horn Res 37:539-582.

Sato M, Kiyama H, Tohyama M (1992) Different postnatal development of cells expressing mRNA encoding neurotensin receptor. Neuroscience $46: 137-149$.

Schmid SL, Fuchs R, Male P, Mellman I (1988) Two distinct subpopulations of endosomes involved in membrane recycling and transport to lysosomes. Cell 52:73-83.

Smythe E, Warren G (199l) The mechanism of receptor-mediated endocytosis. Eur J Biochem 689-699.

Sorkin A, Carpenter G (1993) Interaction of activated EGF receptors with coated pit adaptins. Science 261:612-615.

Sorkin A, Waters CM (1993) Endocytosis of growth factor receptors. Bioessays 15:375-382.

Svoboda M, De Neef P, Tastenoy M, Christophe J (1988) Molecular characteristics and evidence for internalization of vasoactive intestinal peptide (VIP) receptors in the tumoral rat pancreatic acinar cell line AR 4-2J. Eur J Biochem 76:707-713.

Szigethy E, Beaudet A (1987) Selective association of neurotensin receptors with cholinergic neurons in the basal forebrain. Neurosci Lett $83: 47-52$.

Szigethy E, Wenk GL, Beaudet A (1989) Anatomical substrate for neurotensin-acetylcholine interactions in the basal forebrain. Peptides 9:1227-1234.

Szigethy E, Leonard K, Beaudet A (1990) Ultrastructural localization of $\left[{ }^{25} \mathrm{I}\right]$ neurotensin binding sites to cholinergic neurons of the rat nucleus basalis magnocellularis. Neuroscience 36:377-391.

Tanaka K, Masu M, Nakanishi S (1990) Structure and functional expression of the cloned rat neurotensin receptor. Neuron 4:847-854.

Van Deurs B, Holm PK, Kayser L, Sandvig K, Hansen SH (1993) Multivesicular bodies in HEp-2 cells are maturing endosomes. Eur J Cell Biol 61:208-224.

Vanisberg MA, Maloteaux JM, Octave JN, Laduron PM (1991) Rapid agonist-induced decrease of neurotensin receptors from the cell surface in rat cultured neurons. Biochem Pharmacol 42:2265-2274.

Viguerie N, Esteve JP, Susini C, Vaysse N, Ribet A (1987) Processing of receptor-bound somatostatin: internalization and degradation by pancreatic acini. Am J Physiol 252:G535-G542.

Wong SK, Parker EM, Ross EM (1990) Chimeric muscarinic cholinergic: beta-adrenergic receptors that activate Gs in response to muscarinic agonists. J Biol Chem 265:6219-6224.

Wiley HS, Herbst JJ, Walsh BJ, Lauffenburger DA, Rosenfeld MG, Gill GN (1991) The role of tyrosine kinase activity in endocytosis, compartmentation, and down-regulation of the epidermal growth factor receptor. J Biol Chem 266:11083-11094.

Williams JA, Sankaran H, Roach C, Goldfine ID (1982) Quantitative electron microscope autoradiographs of $\left.{ }^{125} \mathrm{I}\right]$-cholecystokinin in pancreatic acini. Am J Physiol 234:G291-G296.

Woulfe J, Checler F, Beaudet A (1992) Light and electron microscopic localization of the neutral metalloendopeptidase EC 3.4.24.16 in the mesencephalon of the rat. Eur J Neurosci 4:1209-1319.

Wynn PC, Suarez-Quain CA, Childs GV, Catt KJ (1986) Pituitary binding and internalization of radioiodinated gonadotropin-releasing hormone agonist and antagonist ligands in vitro and in vivo. Endocrinology 1 19:1852-1863. 